\title{
Identification and Detection of Phoma tracheiphila, Causal Agent of Citrus Mal Secco Disease, by Real-Time Polymerase Chain Reaction
}

\author{
G. Licciardello, Parco Scientifico e Tecnologico della Sicilia, Z. I. Blocco Palma I, Catania, Italy; F. M. Grasso, \\ Dipartimento di Scienze e Tecnologie Fitosanitarie, Università degli Studi di Catania, Catania, Italy; P. Bella, Parco \\ Scientifico e Tecnologico della Sicilia, Catania, Italy; and G. Cirvilleri, V. Grimaldi, and V. Catara, Dipartimento \\ di Scienze e Tecnologie Fitosanitarie, Università degli Studi di Catania, Italy
}

\begin{abstract}
Licciardello, G., Grasso, F. M., Bella, P., Cirvilleri, G., Grimaldi, V., and Catara, V. 2006. Identification and detection of Phoma tracheiphila, causal agent of citrus mal secco disease, by realtime polymerase chain reaction. Plant Dis. 90:1523-1530.

Phoma tracheiphila is the causal agent of a tracheomycotic disease of citrus called mal secco causing the dieback of twigs and branches. This pathogen is of quarantine concern; therefore, fast and reliable protocols are required to detect it promptly. A specific primer pair and a duallabeled fluorogenic probe were used in a real-time polymerase chain reaction (PCR) with the Cepheid Smart Cycler II System (Transportable Device TD configuration) to detect this fungus in citrus samples. Real-time PCR assay was compared to modified conventional PCR assay. The sensitivity of the former was evaluated by testing P. tracheiphila DNA dilutions, and the minimum amount detectable was about $500 \mathrm{fg}$, whereas the linear quantification range was within $100 \mathrm{ng}$ to $1 \mathrm{pg}$. Conventional PCR sensitivity was $10 \mathrm{pg}$. Conventional and real-time PCR successfully detected the fungus in woody samples of naturally infected lemon and artificially inoculated sour orange seedlings. Nevertheless, real-time PCR was about 10 - to 20 -fold more sensitive than conventional PCR, and preliminary results indicate that the former technique achieves quantitative monitoring of the fungus in tissues. Simple and rapid procedures to obtain suitable DNA samples from fungal cultures and citrus woody samples for PCR assays enable diagnosis to be completed in a short time.
\end{abstract}

Additional keywords: Citrus limon, diagnostics, quantitative PCR

Phoma tracheiphila (Petri) Kantschaveli \& Gikashvili is the causal agent of citrus mal secco disease. The principal host is lemon (Citrus limon (L.) Burm. f.), although the disease also has been reported on citron, bergamot, lime, sour orange, and rough lemon (9). Mal secco affects Poncirus, Severinia, and Fortunella spp. as well as Citrus spp. It is most prevalent and severe on lemon and citron trees; lime, bergamot, some mandarin lines, tangelo, and tangor are quite vulnerable; but infection of grapefruit and sweet orange is rare and usually not severe $(3,9,14,27)$. The disease has not been reported in the Americas, Oceania, and some countries in Africa, Australia, and Europe (especially the Iberian Peninsula and Morocco) (9). The European and Mediterranean Plant Protection Organization (EPPO) classifies P. tracheiphila as an A2 quarantine pest. It is of quarantine concern to most regional plant protection services worldwide (APPPC, CPPC, COSAVE, EPPO, IPSC,

Corresponding author: V. Catara

E-mail: vcatara@unict.it

Accepted for publication 4 August 2006.

DOI: 10.1094/PD-90-1523

(C) 2006 The American Phytopathological Society and NAPPO; 9). Furthermore, $P$. tracheiphila is cited among the hazardous plant pathogens that could be used as anticrop chemical weapons (23).

The fungus penetrates the plant through wounds and reaches the vascular system, causing different symptoms, including leaf vein chlorosis, yellowing and leaf drop, twig and branch dieback, and, eventually, the death of the tree $(14,26)$. Two other syndromes are known to be caused by $P$. tracheiphila: "mal fulminante," in which the plant dies rapidly as a result of root infections, and "mal nero" (i.e., a browning of the heartwood as consequence of chronic infections; 27). Removal of the bark of shoots and branches can reveal typical pink-salmon or red discoloration of the xylem. In the Mediterranean region, $P$. tracheiphila is the most destructive fungal disease of lemon. In some cases, infections have affected up to $100 \%$ of the plants of susceptible lemon cultivars; hence, reduction of yield and fruit quality has been reported (14). Pycnidiospores produced in pycnidia differentiated on dead bark tissue and phialoconidia produced on broken parts of plants cause the spread of the disease at short or medium distance (9). Thus, $P$. tracheiphila can be carried by propagation materials both externally and internally within the xylem vessels, such as mycelia, phialoconidia, and blastoconidia $(6,15)$.
No effective method currently is available to control citrus mal secco. The common strategy is to reduce fungal inoculum by pruning withered shoots bearing pycnidia of $P$. tracheiphila, timely removal of suckers, and spraying with authorized fungicides, especially in nurseries (10). Lemon cultivars showing some degrees of resistance to the disease are less popular and are of lower commercial quality (14). Lemon somaclones showing different disease resistance have been reported (12).

Preventive measures, phytosanitary programs, and early diagnosis are the most effective ways to limit the introduction and further spread of the pathogen. Diagnosis of the disease is based mainly on observation of symptoms in the field. Incubation of woody infected samples in humid chambers for 12 to $24 \mathrm{~h}$ may favor exudation of cirrhi (containing conidia) from the pycnidia, thus favoring the identification of the fungus. Conventionally, diagnosis is positive when the fungus is identified in pure culture. The EPPO diagnostic protocol for P. tracheiphila used by National Plant Protection Organizations (NPPOs) to apply phytosanitary measures suggests isolation on potato dextrose agar, carrot agar, or malt extract agar plus chloramphenicol (11). In culture, optimal fungal growth is achieved between 20 and $25^{\circ} \mathrm{C}$; pycnidia develop (preferably on carrot agar) after 5 days at 20 to $25^{\circ} \mathrm{C}$, whereas phialoconidia, produced freely on hyphae, also can be observed after 1 day $(7,18)$. Nevertheless, a molecular method is required in cases where sporulation is not present (11).

Different molecular diagnostic methods used to identify the fungus and detect it in plants have been reported; however, application, time, and operators' skill vary greatly. Electrophoresis of mycelial proteins (polyacrylamide gel electrophoresis [PAGE]) is recommended to identify strains that do not produce pycnidia $(4,11)$. DNA-based molecular techniques have been developed to diagnose $P$. tracheiphila, and include hybridization and PCR assays targeted to an unknown specific DNA target region of a cloned probe from a genomic library of $P$. tracheiphila $(16,17)$ and primers resulting from alignment of internal transcribed spacer ribosomal DNA of Phoma spp. (2). 
The cloned probe developed by Rollo et al. (16), selected from among the recombinant clones of a $P$. tracheiphila genomic library, successfully monitored citrus groves and the presence of the fungus in asymptomatic field samples (i.e., without pink-salmon discolorations of the wood) and in infested soil (8). Two PCR primer pairs and an internal probe then were designed from the 102-bp sequence of a subclone obtained from the initial probe (17). This PCR assay and the subsequent protocol modifications obtained a sensitive and specific testing method for diagnosis of citrus mal secco disease $(1,12,17)$. This technique has been used successfully in routine analysis for presumptive diagnosis at the Dipartimento di Scienze e Tecnologie Fitosanitarie (DISTEF), University of Catania (Italy), to evaluate lemon somaclones for tolerance to the disease (12) and to monitor $P$. tracheiphila colonization in lemon leaves and stems in biocontrol experiments (5). In the course of these tests, unquantifiable differences in fungal concentration were foreseen $(5,8)$.

Recently, real-time PCR, a technique whereby the DNA of a specific target organism can be quantified by measuring the intensity of fluorescence with time during the exponential phase of DNA amplification, increasingly is being used in plant pathology (20). Real-time PCR is more accurate and less time consuming than conventional end-point PCR and eliminates postamplification processing steps. It greatly increases the throughput of PCR testing and, at the same time, decreases ethidium bromide health risks for operators and environmental contamination risks $(20,24)$. This technique proved to be suitable for rapid diagnosis of regulated diseases (21). Applications on a number of fungi, recently reviewed by Schena et al. (24), include qualitative detection and quantitative monitoring of phytopathogenic, antagonistic, and mycorrhizal fungi. Among vascular pathogens, Verticillium dalhiae pathotypes were monitored quantitatively in resistant and susceptible olive genotypes (13).

The objective of this work was to develop a rapid, sensitive assay specific to $P$. tracheiphila that could represent a diagnostic method and a tool for fungus quantitative monitoring in epidemiological and breeding studies. The conventional PCR assay developed by Rollo et al. (17) more than 15 years ago has undergone many modifications during its routine use in our lab; therefore, in this study, we attempted to (i) validate the efficiency of this protocol and (ii) develop an even more specific quantitative assay by means of real-time PCR using TaqMan chemistry. Different sample preparation protocols also were compared.

\section{MATERIALS AND METHODS}

Fungal isolates. A set of $P$. tracheiphila isolates were obtained from lemon trees affected by mal secco in groves located in southern Italy and Greece. These were characterized previously by morphology and maintained in the collection at the DISTEF, University of Catania, Italy (Table 1). Additional Italian isolates were obtained by G. Magnano di San Lio (Università "Mediterranea", di Reggio Calabria, Italy; Table 1). P. tracheiphila strains were grown and maintained on potato dextrose agar (PDA; Oxoid, Milan, Italy) and stored at $4^{\circ} \mathrm{C}$ for short-term studies. Liquid cultures were prepared in Sabouraud liquid medium (Oxoid). Pycnidiospores for plant inoculation were produced after 1 week of incubation at $21^{\circ} \mathrm{C}$ in the dark on carrot agar $(\mathrm{CaA} ; 11)$. Other fungi available at the DISTEF were used to assess assay specificity (Table 1). Two strains of Pseudomonas syringae pv. syringae (PVCT10.2 and PVCT48Sr2) isolated from Citrus spp. also were included.

Citrus samples. Citrus materials for test development were obtained from either artificially inoculated or naturally infected plants. One-year-old sour orange (Citrus aurantium) seedlings were inoculated by adding $20 \mu \mathrm{l}$ of a water suspension containing Phoma tracheiphila strain Pt1A at $10^{6}$ conidia $\mathrm{ml}^{-1}$ into a cut in the bark made by a scalpel. Inoculations were performed during the growing season and the plants were maintained in the open under a black shade cloth. Plants were grown in a glasshouse and samples were collected throughout the experiment, which started 1 month after inoculation. Field samples were obtained from mal secco-affected lemon groves located in Sicily and Calabria (southern Italy). Twigs showing dieback of the distal portion were collected. The bark was partially peeled off to assess the presence of the characteristic salmon-pink discoloration of the wood. Serial transversal sections of twigs were taken, moving from the symptomatic tissues toward the asymptomatic (no discoloration) ones. Sections of healthy sour orange and lemon trees were obtained from commercial nursery plants. Each sample was divided into two adjacent sections, and one of the two was processed for DNA extraction, whereas the other was surface sterilized in $1 \%$ o $\mathrm{HgCl}_{2}$ for $30 \mathrm{~s}$, washed four times in sterile water, plated on PDA (divided into five portions), and incubated at $21^{\circ} \mathrm{C}$ for 8 days. Resulting fungal colonies were identified by morphology.

Preparation of DNA template. Two main methods were used for fungal and plant DNA extraction. Fungal DNA extraction utilized a few hyphae of a 5-day-old colony of $P$. tracheiphila inoculated in 30 $\mathrm{ml}$ of Sabouraud liquid medium (Oxoid). Following growth at $24^{\circ} \mathrm{C}$ for 5 days, total DNA was extracted from $60 \mathrm{mg}$ of fresh mycelium washed twice in sterile distilled water, using a Puregene Genomic DNA isolation kit (Gentra Systems, Minneapolis, MN), according to the manufacturer's instructions. The second protocol used a quick DNA extraction method slightly modified from that of Wang et al. ( $\mathrm{NaOH}$ method; 30). Mycelium of 3-day-old fungal culture grown in Eppendorf tubes containing $1 \mathrm{ml}$ of Sabouraud liquid medium was homogenized with a pestle in a $1.5-\mathrm{ml}$ Eppendorf tube containing from 50 to 200 $\mu \mathrm{l}$ of $5 \mathrm{~N} \mathrm{NaOH}$. Aliquots $(5 \mu \mathrm{l})$ of the slurry were transferred in $495 \mu \mathrm{l}$ of $20 \mathrm{mM}$ Tris-HCl. DNA samples were stored at $4^{\circ} \mathrm{C}$ for the duration of the experiments. Conventional PCR assays also were performed by transferring small hypha portion directly into the PCR reaction tube with a needle.

Citrus twig sections (about $200 \mathrm{mg}$ of tissue) obtained from either artificially or naturally infected plants were ground in liquid nitrogen until a fine powder was obtained. DNA was extracted from $60 \mathrm{mg}$ of the ground samples with either the Puregene Genomic DNA isolation kit (Gentra Systems) or the $\mathrm{NaOH}$ method.

PCR methods. PCR amplifications were performed with two pairs of primers. The first primer pair, GR70 (5'GATCCGTACGCCTTGGGGAC- $3^{\prime}$ ) and GR71 (5'-GATCCGAGCGGGACGAGC AG-3'), described by Rollo et al. (17), targeted a 102-bp DNA region of $P$. tracheiphila DNA. The second pair consisted of the previous forward primer GR70 and a new reverse primer, GL1 (5'-AGAAGC GTTTGGAGGAGAGAATG-3'), designed from the same DNA region by using Primer Express software (v2; Applied Biosystem, Monza, Italy) and amplifying an 84-bp DNA segment. A dual-labeled fluorogenic probe, PP1, (5'-FAMCACGCAATCTTGGCGACTGTCGTTTAMRA-3'), was designed within the DNA segment to allow fluorescent detection of amplification products by real-time PCR.

Conventional PCR reactions were carried out using either one or the other pair of primers with conditions slightly modified from those described in Gentile et al. (12), in 50- $\mu$ l reaction mix containing: PCR buffer (Invitrogen Life Technologies, Milan, Italy), $1.5 \mathrm{mM} \mathrm{MgCl} 2,0.2 \mathrm{mM}$ each dNTP, $200 \mathrm{nM}$ primers, and $1.25 \mathrm{U}$ of Taq DNA Recombinant Polymerase (Invitrogen). Aliquots (1 to $5 \mu \mathrm{l}$ ) of the DNA extracted from $P$. tracheiphila and from citrus tissues were used as the template source. Amplifications were carried out in a thermal cycler GeneAmp PCR system 9700 (Applied Biosystem) programmed for one cycle of $4 \mathrm{~min}$ at $94^{\circ} \mathrm{C}$ followed by 40 cycles of $30 \mathrm{~s}$ at $94^{\circ} \mathrm{C}, 30 \mathrm{~s}$ at $58^{\circ} \mathrm{C}$, and $30 \mathrm{~s}$ at $72^{\circ} \mathrm{C}$. Amplified products were resolved by electrophoresis at 5.7 volt $\mathrm{cm}^{-1}$ in $2 \%$ agarose gel in $1 \times$ Tris-acetate-EDTA buffer and visualized after staining with ethidium bromide (19).

Real-time PCR assays were performed using lyophilized beads OmniMix HS 
(Cepheid, Sunnyvale, CA). Each bead was used for two 25- $\mu$ l total final volume reactions. We added $200 \mathrm{nM}$ forward primer, $200 \mathrm{nM}$ reverse primer, $100 \mathrm{nM}$ fluorogenic probe, and either $1 \mu \mathrm{l}$ of genomic DNA for samples extracted with the kit or $5 \mu$ of DNA obtained with the $\mathrm{NaOH}$ method. Negative control reactions contained the same mixture, with sterile water replacing the DNA template. All PCR reactions were performed in 25- $\mu$ l Smart Cycler reaction tubes (Cepheid) in a Smart Cycler II System (Transportable Device
TD configuration; Cepheid). The thermal cycling conditions for $P$. tracheiphila DNA template amplification were initial denaturation at $95^{\circ} \mathrm{C}$ for $30 \mathrm{~s}$ followed by 40 cycles at $95^{\circ} \mathrm{C}$ for $10 \mathrm{~s}, 62^{\circ} \mathrm{C}$ for $15 \mathrm{~s}$, and $72^{\circ} \mathrm{C}$ for $15 \mathrm{~s}$, with heating ramp rates (max) of $10^{\circ} \mathrm{C} \mathrm{s}^{-1}$ and cooling ramp rates $(\max )$ of $25^{\circ} \mathrm{C} \mathrm{s}^{-1}$. For each sample, detection was performed by online monitoring to identify the exact threshold cycle $(\mathrm{Ct})$ value where the log-linear phase could be distinguished from the background. All reactions were analyzed by $2 \%$ agarose gel electrophoresis to confirm that only PCR products were amplified.

Conventional and real-time PCR assays were performed at least twice for each fungal isolate.

Sensitivity of the assays and real-time PCR quantification of template. Calibration of the standard curve for fungal DNA quantification by real-time PCR was assessed using P. tracheiphila DNA (100 $\mu \mathrm{g}$ $\mathrm{ml}^{-1}$ ) extracted from strain Pt1A and serially diluted in sterile distilled water. The PCR product of GR70 and GL1 was

Table 1. Isolates of Phoma tracheiphila and of other fungal species used in this study

\begin{tabular}{|c|c|c|c|c|}
\hline Species, isolate & $\begin{array}{c}\text { Geographic } \\
\text { origin }^{\mathrm{a}}\end{array}$ & Host $^{b}$ & Year $^{\mathrm{c}}$ & Source \\
\hline \multicolumn{5}{|l|}{ P. tracheiphila } \\
\hline Pt 1.A & Italy (Sicily-CT) & Citrus limon & $\ldots$ & DISTEF \\
\hline Pt 1.B & Italy (Sicily-CT) & C. limon & $\ldots$ & DISTEF \\
\hline Pt 2.A & Italy (Sicily-CT) & C. limon & $\ldots$ & DISTEF \\
\hline Pt 2.B & Italy (Sicily-CT) & C. limon & $\ldots$ & DISTEF \\
\hline Pt 71 & Italy (Sicily-CT) & C. limon & 1983 & G. Magnano di San Lio \\
\hline Pt 12 & Italy (Sicily-CT) & C. limon & 2005 & DISTEF \\
\hline Pt 28 & Italy (Sicily-CT) & C. limon & 2005 & DISTEF \\
\hline Pt 4 & Italy (Sicily- SR) & C. limon & 2005 & DISTEF \\
\hline Pt 14 & Italy (Sicily-ME) & C. limon & 2005 & DISTEF \\
\hline Pt $15 \mathrm{~T}$ & Italy (Sicily-ME) & C. limon & 2005 & DISTEF \\
\hline Pt $18 \mathrm{~T}$ & Italy (Sicily-ME) & C. aurantium & 2005 & DISTEF \\
\hline Pt 21 & Italy (Sicily-ME) & C. limon & 2005 & DISTEF \\
\hline Pt 23 & Italy (Sicily-ME) & C. aurantium & 2005 & DISTEF \\
\hline Pt52 & Italy (Sicily-PA) & C. limon & 1983 & G. Magnano di San Lio \\
\hline Pt 27 & Italy (Sicily-PA) & C. limon & 2005 & DISTEF \\
\hline Pt 30 & Italy (Sicily-PA) & C. medica & 2005 & DISTEF \\
\hline Pt 31 & Italy (Sicily-PA) & C. aurantium & 2005 & DISTEF \\
\hline Pt 61 & Italy (Sicily-SR) & C. limon & 1983 & G. Magnano di San Lio \\
\hline Pt 8T & Italy (Sicily-SR) & C. limon & 2005 & DISTEF \\
\hline Pt 76 & Italy (Calabria-RC) & C. aurantium & 2005 & DISTEF \\
\hline Pt 83 & Italy (Calabria-CS) & C. limon & 2005 & DISTEF \\
\hline Pt 82 & Italy (Calabria-CZ) & C. limon & 2005 & DISTEF \\
\hline Volk & $\ldots$ & C. volkameriana & 1992 & G. Magnano di San Lio \\
\hline Pt VIII & $\ldots$ & $\ldots$ & 1982 & G. Magnano di San Lio \\
\hline Pt 57 & Greece & C. limon & 2005 & DISTEF \\
\hline Pt 59 & Greece & C. limon & 2005 & DISTEF \\
\hline Pt 62 & Greece & C. limon & 2005 & DISTEF \\
\hline Pt 64 & Greece & C. limon & 2005 & DISTEF \\
\hline Pt 69 & Greece & C. limon & 2005 & DISTEF \\
\hline Pt 74 & Greece & C. limon & 2005 & DISTEF \\
\hline \multicolumn{5}{|l|}{ Alternaria sp. } \\
\hline Alt17 & Italy & Mandarin hybrid 'Fortune'd & 2001 & DISTEF \\
\hline Alt36 & Italy & Mandarin hybrid 'Fortune'd & 2001 & DISTEF \\
\hline Alternaria citri AltC11 & Italy & Mandarin hybrid 'Primosole'd & 1998 & DISTEF \\
\hline Armillaria mellea ArmG1 & Italy & Betula pendula & 2005 & DISTEF \\
\hline \multicolumn{5}{|l|}{ Aspergillus niger } \\
\hline MUCL29039 & United States & Vaccinium sp. & 1997 & BCCM/MUCL \\
\hline MPVCT164 & Italy & Vitis vinifera & 2005 & DISTEF \\
\hline Botrytis cinerea $\mathrm{Bc} 22$ & Italy & Lycopersicon lycopersicum & 1997 & DISTEF \\
\hline Colletotrichum gloeosporioides $\mathrm{CgF} 1$ & Italy & C. limon & 2004 & DISTEF \\
\hline Fusarium solani $\mathrm{Fs} 1 \mathrm{~A}$ & Italy & Troyer citrange (Poncirus trifoliata $\times$ C. sinensis) & $\ldots$ & PSTS \\
\hline \multicolumn{5}{|l|}{ Mycosphaerella citri } \\
\hline SAS-02 & United States & C. paradisi & 2001 & L. W. Timmer \\
\hline SAS-06 & United States & C. paradisi & 2001 & L. W. Timmer \\
\hline \multicolumn{5}{|l|}{ Penicillium digitatum } \\
\hline MPVCT233 & Italy & C. sinensis & 2002 & DISTEF \\
\hline MPVCT33 & Italy & C. sinensis & 2004 & DISTEF \\
\hline P. italicum MPVCT36 & Italy & C. sinensis & 2004 & DISTEF \\
\hline Phytophthora citrophthora $\mathrm{Pc} 6 \mathrm{~B}$ & Italy & C. aurantium & 2004 & PSTS \\
\hline Phoma exigua var. heteromorpha $\mathrm{PH} 1$ & Italy & Nerium oleander & 2004 & DISTEF \\
\hline Verticillium alboatrum VertG1 & Italy & Solanum melongena & 2004 & DISTEF \\
\hline
\end{tabular}

${ }^{a}$ Geographic origin of Italian P. tracheiphila isolates indicated in parentheses (region and acronym of the province).

b ... = Not known.

c DISTEF = Dipartimento di Scienze e Tecnologie Fitosanitarie, University of Catania, Italy; G. Magnano di San Lio, Università "Mediterranea" di Reggio Calabria, Italy; BCCM/MUCL = Belgian Coordinated Collections of Microorganisms/Mycotheque de l'Universite Catholique de Louvain, Louvain la Neuve, Belgium; PSTS, = Parco Scientifico e Tecnologico della Sicilia, Catania, Italy; L. W. Timmer, University of Florida, CREC, Lake Alfred.

d Mandarin hybrid 'Fortune', C. clementina 'Fina' $\times$ C. tangerina 'Dancy'; Mandarin hybrid 'Primosole', C. unshiu 'Miho' $\times$ C. reticulata 'Carvalhais'. 
cloned to evaluate the number of target DNA copies detected by real-time PCR. PCR product was purified using QIAquick Kit (Qiagen, Milan, Italy) and cloned into pCRII vector by TOPO TA cloning (Invitrogen). White transformants were selected on solid L medium containing ampicillin at $50 \mu \mathrm{g} \mathrm{ml}^{-1}$ and prespread with $40 \mu \mathrm{l}$ of $\mathrm{X}$ gal at $40 \mathrm{mg} \mathrm{ml}^{-1}$ and $40 \mu \mathrm{l}$ of $100 \mathrm{mM}$ IPTG. Plasmid DNA was purified from the transformants with QIAquick Plasmid Mini Kit (Qiagen). The presence of the insert was confirmed after enzymatic digestion with EcoRI. The recombinant 4-kb pPT5 plasmid (DNA at $130 \mu \mathrm{g} \mathrm{ml}^{-1}$ representing $3.5 \times 10^{10}$ copies $\left.\mu^{-1}\right)$ containing P. tracheiphila PCR target sequence was serially diluted with double-distilled sterile water to calibrate real-time PCR. Standard curves for both samples were obtained by plotting the $\mathrm{Ct}$ values versus the logarithm of the concentration of each 10-fold dilution series. $\mathrm{Ct}$ values for each standard reaction were calculated on three PCR replications, performed in three separate runs.

\section{RESULTS}

Specificity and sensitivity of $P$. tracheiphila primers for conventional PCR. Primer pairs (GR70-GR71 and GR70GL1) were tested by conventional PCR with organisms in Table 1. A unique DNA amplicon of the expected size, either 102 or $84 \mathrm{bp}$, was obtained from all the $30 P$. tracheiphila isolates with primer pairs GR70-GR71 and GR70 and GL1, respectively (Fig. 1). Strains were obtained in different years, prevalently from lemon groves located in different geographic areas; chromogenic and non-chromogenic strains were included. No amplification was achieved from DNA of fungal species isolated from either citrus or other plants (Fig. 2), or Pseudomonas syringae pv. syringae strains PVCT10.3 and IPVCT48.Sr2 isolated from lemon. Both pairs of primers detected $P$. tracheiphila up to $10 \mathrm{pg}$ of DNA (Fig. 3). DNA target amplification from $P$. tracheiphila was

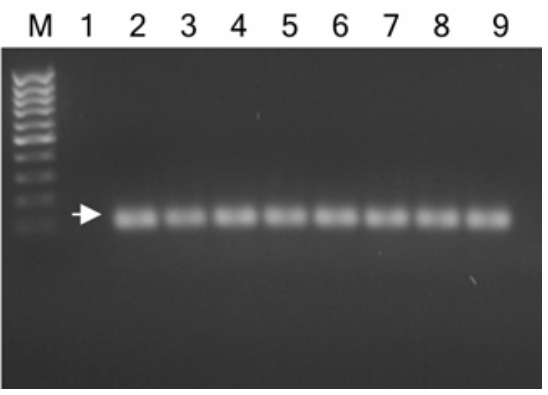

Fig. 1. Polymerase chain reaction amplification of genomic DNA from different isolates of Phoma tracheiphila using primer pair GR70GL1 (product $84 \mathrm{bp}$ ). Lanes 2-9, P. tracheiphila isolates Pt1A, Pt2A, Pt11, Pt21, Pt27, Pt57, Pt52, and Pt VIII. Lane 1, water control. M, molecular marker, GeneRuler 100-bp DNA Ladder (Fermentas, Milan, Italy). Arrow indicates the 84-bp product.

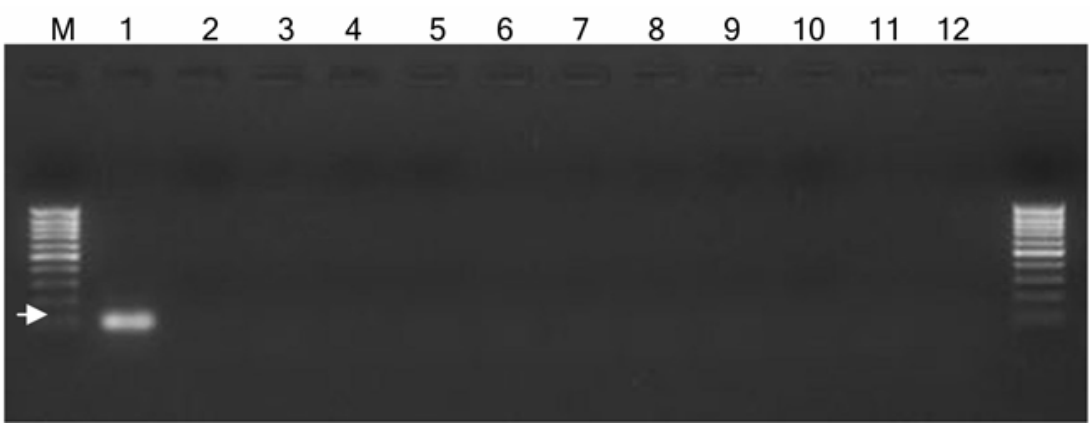

Fig. 2. Representative agarose gel electrophoresis of polymerase chain reaction performed to assess specificity of the primers against some other fungal species with primer pair GR70-GL1. Lane 1, positive control Phoma tracheiphila strain Pt62; lane 2, Aspergillus niger; lane 3, Penicillium italicum lane 4, P. digitatum; lane 5, Colletotrichum gloeosporioides; lane 6, an Alternaria sp.; lane 7, Alternaria citri; lane 8, Fusarium solani; lane 9, Phoma exigua; lane 10, an Alternaria sp.; lane 11, water control. M, molecular marker, GeneRuler 100-bp DNA Ladder (Fermentas). Arrow on the left indicates the 84-bp product.

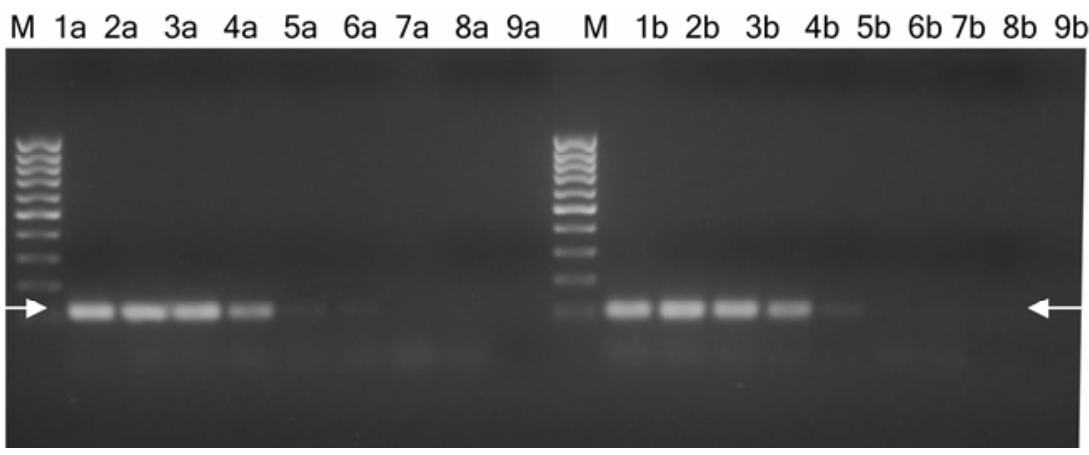

Fig. 3. Sensitivity of conventional polymerase chain reaction performed with primers GR70-GR71 (lanes 1a-9a) and GR70 and GL1 (lanes 1b-9b) using serial dilutions of Phoma tracheiphila DNA. Lane 1, $100 \mathrm{ng}$; lane 2, $10 \mathrm{ng}$; lane 3,1 ng; lane 4, $0.1 \mathrm{ng}$; lane 5, $0.01 \mathrm{ng}$; lane 6, $0.005 \mathrm{ng}$; lane 7, $0.001 \mathrm{ng}$; lane 8, $0.0005 \mathrm{ng}$; lane 9, water control. M, molecular weight marker, GeneRuler 100-bp DNA Ladder (Fermentas). Arrows on the left and right indicate the 102- and 84-bp products, respectively.

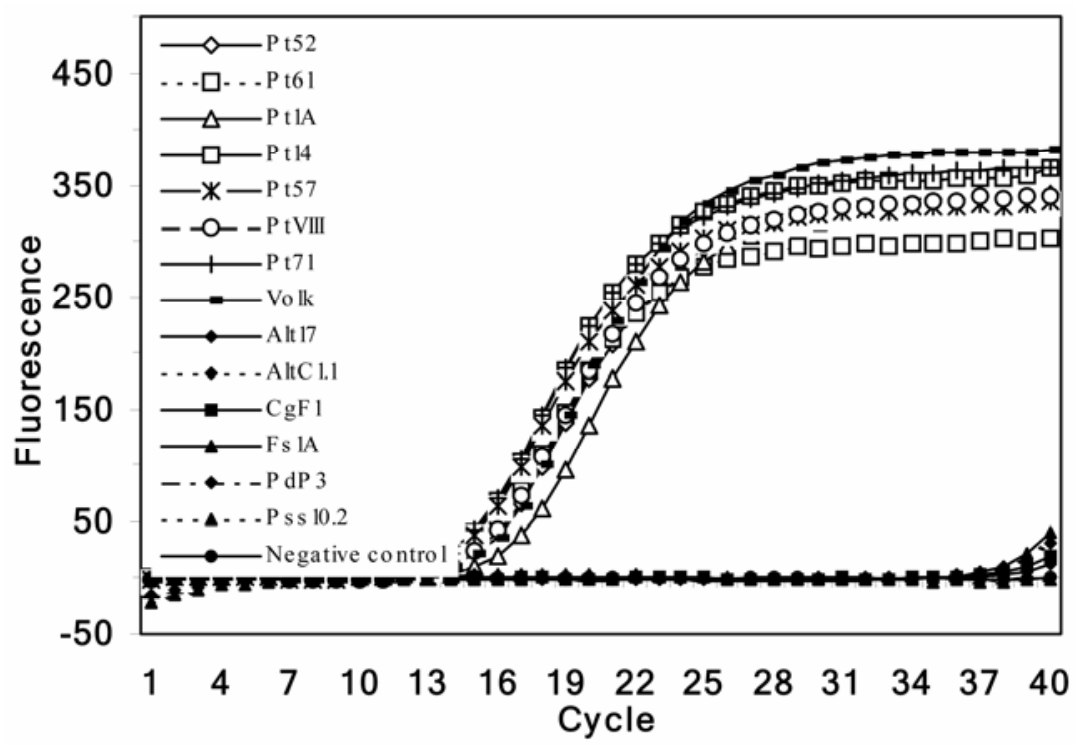

Fig. 4. Real-time polymerase chain reaction amplification of genomic DNA of different isolates of Phoma tracheiphila (Pt1.A, Pt 14, Pt 52, Pt 57, Pt 61, Pt 71, Pt VIII, and Volk) where increasing fluorescence was detected by the instrument, and of other Citrus sp.-associated microorganisms (Alt17, AltC11, CgF1, Fs1A, MPVCT33, and Pss10.2) where no fluorescence was detected. Data from Smart Cycler software 2.0 were exported as graph data to build a black-and-white picture by using Microsoft Excel. 
achieved successfully by conventional PCR with primers GR70 and GL1 when using DNA as template and when a small hypha portion was added directly into the PCR (data not shown).

Detection of $P$. tracheiphila in citrus plants by conventional PCR. $P$. tracheiphila was detected consistently with both pairs of primers in lemon and sour orange plants inoculated with pycnoconidia of the fungus, and no signals were detected from uninoculated controls. Artificially inoculated plants showed the first disease symptoms (i.e., leaf-vein chlorosis) about 4 weeks after fungal inoculation. PCR of DNA from twig sections was positive in all 20 analyzed samples after DNA extraction with the kit (see Materials and Methods), whereas 14 of 20 samples were positive after processing with the $\mathrm{NaOH}$ method. Samples obtained by the former method yielded stronger signals compared with those obtained by the $\mathrm{NaOH}$ method (data not shown). Regardless of the extraction method, better signals were observed with tender samples (such as small young twigs) than with lignified samples.

Real-time PCR assay. In real-time PCR assays, total DNAs from 30 P. tracheiphila isolates (DNA concentration 90 to $150 \mu \mathrm{g}$ $\mathrm{ml}^{-1}$ ) yielded a significant increase of fluorescence, as detected by Smart Cycler II System after about the 12th cycle. In all of the experiments, the threshold was set manually to 30 . Under these conditions, Cts ranging from 13 to 16 were obtained (Fig. 4). Specificity of both primers and probe was confirmed when no signals were generated for DNA extracts from the other fungal species (Fig. 4). Agarose gel electrophoresis analysis and ethidium bromide staining of the real-time PCR products showed a positive correlation between the fluorescence and the amplification of the expected DNA fragment (data not shown).

To calibrate the real-time PCR, 10-fold serial dilutions of $P$. tracheiphila DNA and the recombinant pPT5 plasmid containing the target sequence were used. For all of the experiments, the Smart Cycler II System instrument recorded the fluorescent light emission accumulating with the number of cycles and depending on the initial amount of template DNA. For the amplification of $P$. tracheiphila DNA, the standard curve was obtained by plotting $\mathrm{Ct}$ values versus the DNA concentration of each 10-fold-dilution series. The standard curve was linear over six log units of initial quantities of template DNA spanning from $1 \times 10^{2}$ to $1 \times 10^{-3} \mu \mathrm{g} \mathrm{ml}^{-1}$, with a correlation coefficient $\left(R^{2}\right)$ of 0.991 (Fig. 5A). Therefore, the minimum amount of pathogen DNA that could be quantified accurately in our assays was $1 \mathrm{pg}$, corresponding to a $\mathrm{Ct}$ value of 37.93. Nevertheless, though the $\mathrm{Ct}$ values were not linear, amplification of $P$. tracheiphila in samples of
$500 \mathrm{fg}$ still could be detected by the instrument and confirmed by agarose gel electrophoresis.

For the recombinant plasmid, the $\mathrm{Ct}$ values were plotted versus the log of the initial copy number of the template DNA (Fig. 5B). The data indicate that starting amounts of the recombinant $P$. tracheiphila plasmid ranging from at least $3.5 \times 10^{9}$ to $3.5 \times 10^{4}$ copies $\mu \mathrm{l}^{-1}$ were detected within the linear regression dynamic range of the fluorescence detection assay $\left(R^{2}=0.998\right)$. The standard deviation for each point of the standard curve (Fig. 5) increased by decreasing initial DNA concentration or target copy number.
Quantitative detection of $P$. tracheiphila in citrus samples by real-time PCR. P. tracheiphila was detected by realtime PCR assay in twigs of artificially inoculated sour orange seedlings as well as in twigs of lemon trees affected by mal secco disease sampled in citrus orchards. No fluorescence was detected when analyzing DNA extracted from healthy sour orange and lemon samples. $\mathrm{Ct}$ values resulting from the assays with unknown samples were plotted against the standard curve and the inferred concentration of $P$. tracheiphila was calculated. A Ct of about 37 (1 pg of the DNA according to the standard curve) was considered to be the
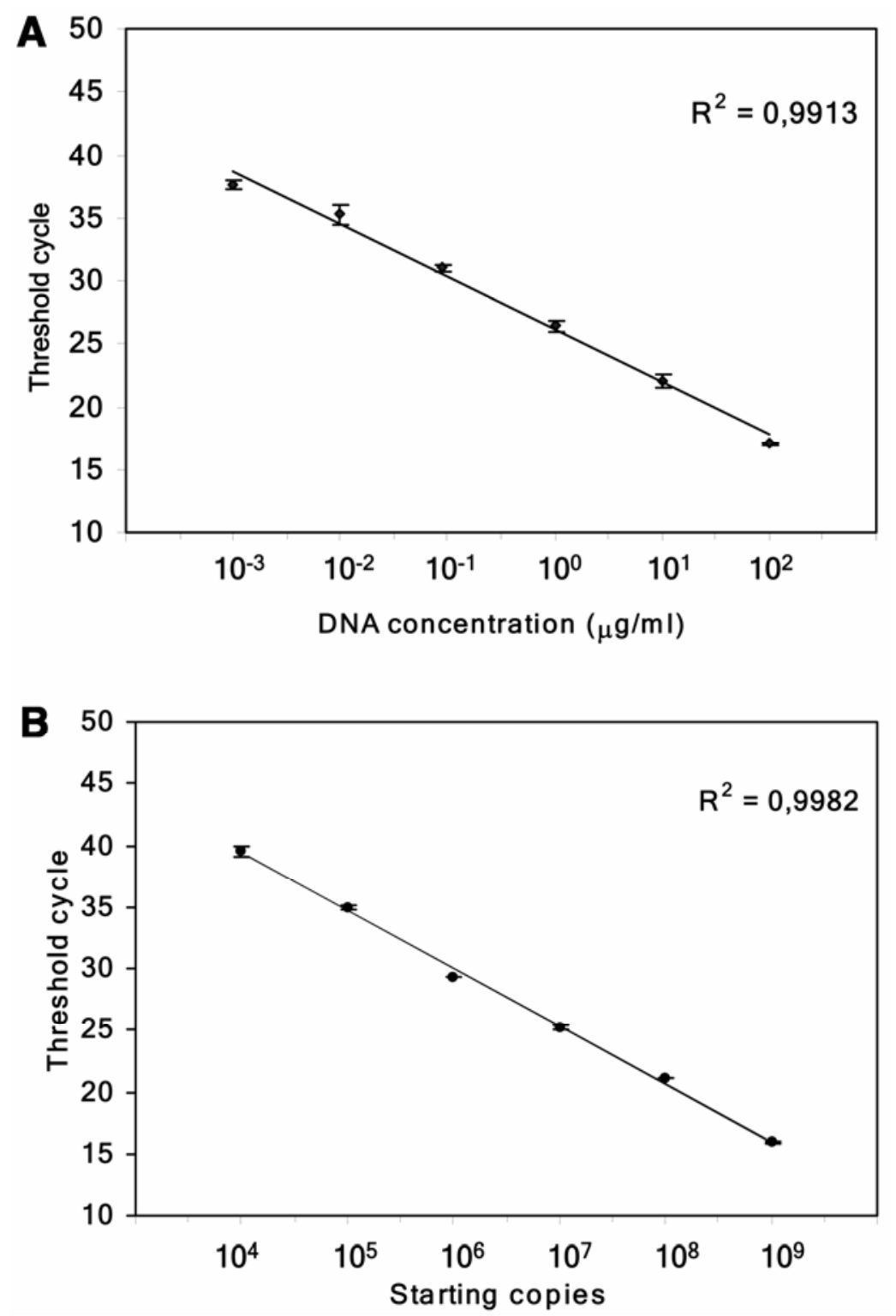

Fig. 5. Calibration curves for the absolute quantification of Phoma tracheiphila using either A, genomic DNA or $\mathbf{B}$, the recombinant plasmid DNA containing genomic sequence target. A, Standard curve was generated from threshold cycle numbers (Ct value) of dilutions of $P$. tracheiphila DNA plotted versus the quantity of template $\mathrm{E} 1=100 \mathrm{ng}, 2=10 \mathrm{ng}, 3=1 \mathrm{ng}, 4=0.1 \mathrm{ng}, 5=0.01 \mathrm{ng}$, and 6 $=0.001 \mathrm{ng}$. B, Starting copy number of template DNA present in each reaction is indicated by the number $1=3.5 \times 10^{9}, 2=3.5 \times 10^{8}, 3=3.5 \times 10^{7}, 4=3.5 \times 10^{6}, 5=3.5 \times 10^{5}$, and $6=3.5 \times 10^{4}$. The threshold number of polymerase chain reaction cycles was plotted versus the starting number of target copies per microliter of plasmid DNA extract. $R^{2}=$ correlation coefficient. Error bars represent standard deviation from three replicates for each dilution obtained in three independent runs. 
threshold value in the standard curve suitable for quantification. The fungus was detected in all of the 40 samples tested that showed discoloration of the vascular tis- sues, with Cts ranging from 24 to 31 (i.e., 1,650 to $43 \mathrm{pg}$ of DNA per reaction) when using the standard protocol and samples consisting of an aliquot of liquid nitrogen-
Table 2. Detection of Phoma tracheiphila by conventional and real-time quantitative polymerase chain reaction $(\mathrm{PCR})$ in twigs sampled from naturally infected lemon trees ${ }^{\mathrm{a}}$

\begin{tabular}{lcccc}
\hline Twig section analyzed & $\begin{array}{c}\text { No. of } \\
\text { samples }\end{array}$ & $\begin{array}{c}\text { Positive by } \\
\text { conventional } \\
\text { PCR (\%) }\end{array}$ & $\begin{array}{c}\text { Positive by real- } \\
\text { time PCR }(\%))^{\mathbf{b}}\end{array}$ & $\begin{array}{c}\text { Real-time PCR } \\
\text { quantification of } \\
\text { DNA (pg/reaction) }\end{array}$ \\
\hline Beneath withered tissues & 20 & 100 & 100 & $821-1,650$ \\
Intermediate & 20 & 90 & 100 & $43-564$ \\
Symptomless & 30 & 20 & 80 & $7.8-35.3$ \\
\hline
\end{tabular}

a Symptomatic twigs were cut in transverse sections starting from the tissue beneath the withered part toward parts that did not show internal vascular discoloration (symptomless). DNA was extracted from $60 \mathrm{mg}$ of ground tissue.

${ }^{\mathrm{b}}$ Conventional PCR with primers GR70-GL1 was performed as described in Materials and Methods.

${ }^{c}$ Range of DNA quantified in tested samples.
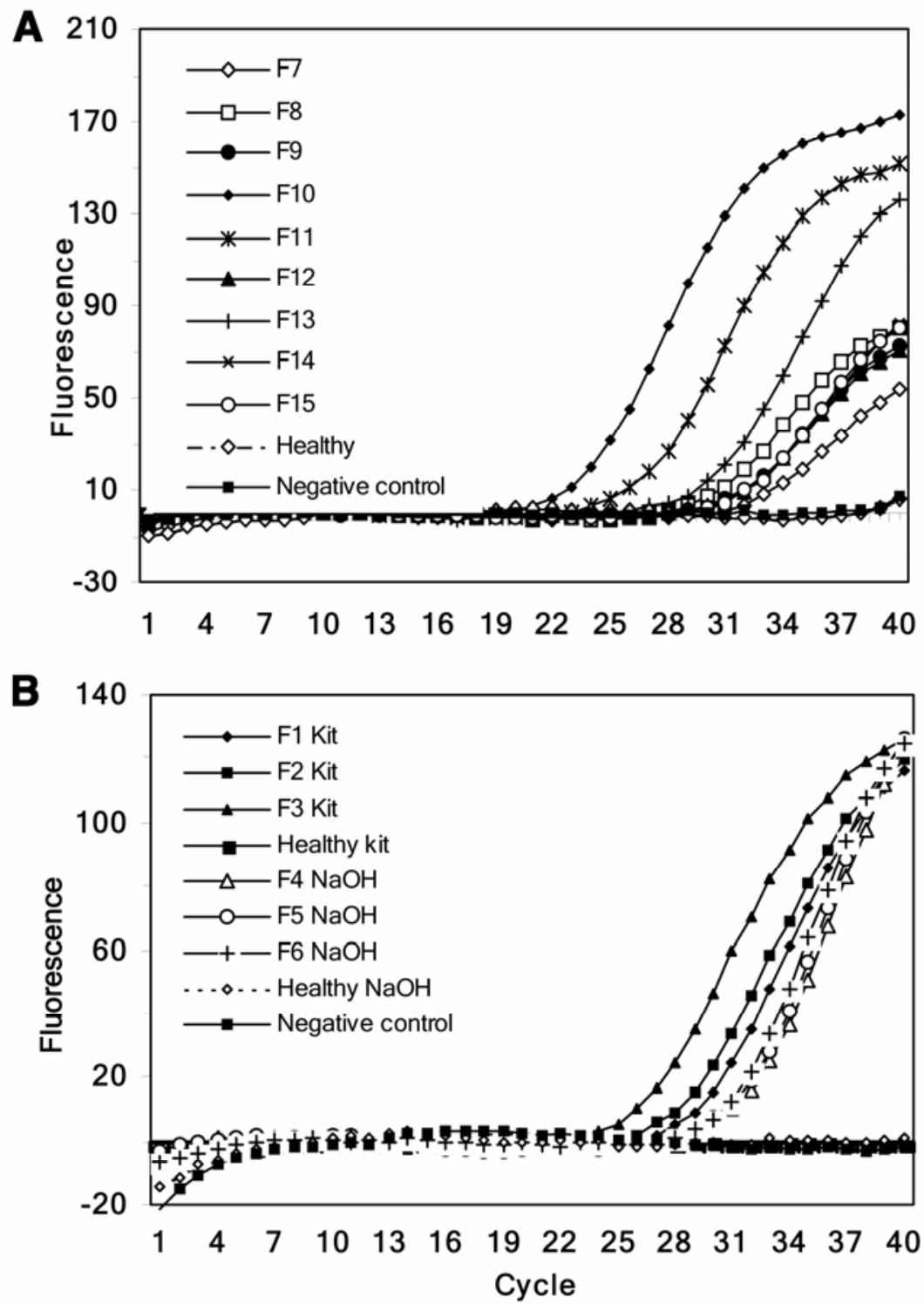

Fig. 6. Examples of detection of Phoma tracheiphila in Citrus plants affected by mal secco using realtime polymerase chain reaction (PCR). A, Field samples (F7-F15) analyzed by the real-time PCR assay following DNA extraction with the commercial kit: only samples F10, F11, and F14 reaching the threshold cycle $(\mathrm{Ct})$ before the 30th cycle also were identified as positive by conventional PCR. B, Effect of DNA extraction method on Ct as assessed on companion lemon twig sections extracted by the Puregene Genomic DNA isolation kit versus the $\mathrm{NaOH}$ method; DNAs from healthy citrus samples were included as well as a water control (see legend). Data from Smart Cycler software 2.0 were exported as excel data to build black-and-white graphs by using Microsoft Excel. ground twig sections (Table 2). In greater detail, $P$. tracheiphila DNA quantified from samples collected just beneath the dead section of the twig and near the discolored xylem tissue ranged from 821 and $1,650 \mathrm{pg}$ per reaction. In twigs showing partial discoloration of the xylem, DNA concentrations ranged from 43 to $564 \mathrm{pg}$ per reaction. Lower Cts (earlier detection) were recorded when the DNA was extracted directly from only the discolored tissue and not from the entire twig section (data not shown). Ct values obtained by real-time PCR analysis of asymptomatic twig sections excised from symptomatic twigs, when positive to the assay, ranged from 31 to 34.7 , quantifiable as about 35.3 pg to $7.8 \mathrm{pg}$ of DNA per reaction (Table 2). No fluorescence was detected in 6 of the 30 tested samples. Increasing $\mathrm{Cts}$ were observed when analyzing the same twig going from the symptomatic to asymptomatic tissue sections (Fig. 6A). Ct value analysis in relation to the standard curve of the recombinant plasmid detected a range corresponding approximately to 500 to $1,000,000$ copies per target sequence. $\mathrm{Ct}$ interpolation with the recombinant plasmid standard curve detected between 1,000 and 500,000 DNA copies in the infected tissue. A subset of samples extracted by the $\mathrm{NaOH}$ procedure was analyzed. These samples reached the $\mathrm{Ct}$ about three to five cycles later than samples extracted with the kit, although $5 \mu \mathrm{l}$ of sample were used as the template (Fig. 6B). Conventional PCR with the primer pairs GR70-GR71 and GR70-GL1 was performed on all plant extracts processed by real-time PCR. Conventional PCR detected $P$. tracheiphila generally only in samples reaching $\mathrm{Ct}$ before the 30th cycle by real-time PCR (Fig. 6A).

Isolation of the fungus on PDA generally agreed with the real-time PCR assay results. P. tracheiphila was recovered following plating on PDA in four to five of the five plated pieces of tissue for each section of twig adjacent to those positive to real-time PCR and obtained from twigs showing vascular discoloration. The number of positive isolations per plate decreased as the symptoms became less severe, and zero to two pieces of the five were positive when plating asymptomatic samples. The identity of the fungus was confirmed preliminarily by PCR by transferring a fungal hypha collected from colonies on PDA to a PCR tube, and further confirmed with conventional methods based on colony and pycnidial morphology as described in the EPPO protocol (11). The real-time PCR assay also was able to detect $P$. tracheiphila in samples where other fungal species were obtained on PDA (namely, Colletotrichum and Alternaria spp.). A subset of 10 of these fungal strains did not produce any fluorescence when analyzed by real-time PCR. 


\section{DISCUSSION}

$P$. tracheiphila is an important citrus pathogen. Thus, suitable tools for its detection in propagating materials or its early identification in the field are very important. This article describes protocols involving conventional or real-time PCR and reliable DNA extraction methods that allow rapid identification of cultures of $P$. tracheiphila and its detection in plant tissues. Furthermore, the real-time assay developed represents a fast and simple method for quantitative detection of the fungus in citrus tissues.

The specificity of the target sequence used in this article to detect $P$. tracheiphila has been tested over the years, because it derives from a cloned probe that is known to hybridize with a set of strains of this species and not with a Diplodia sp., Cytosporina citriperda, Diplodia aurantia, Penicillium spp., Alternaria citri, Septoria arethusa, an Aspergillus sp., Phoma lycopersici, P. destructiva, and Citrus spp. DNA in dot-blot assays (16). In fact, hybridization and PCR assays were performed for diagnostic or epidemiological purposes $(1,5,9,12,16,17)$. Nevertheless, in this article, we validated the new PCR conditions and DNA extraction protocols both with Rollo et al.'s primers (17) and using the new primer pair designed specifically for this real-time PCR study. The specificity and reliability of the system was confirmed by testing $30 \quad P$. tracheiphila isolates and nine other fungal species. Furthermore, the system was tested on plant samples potentially carrying other microorganisms both epiphytically and as endophytes. This highsensitivity assay also detected $P$. tracheiphila in samples not presenting the typical pinkish wood discoloration considered a distinctive symptom of the disease. Nonspecific amplification products were not observed when testing other fungal species or plant DNA samples by conventional PCR used in this study. The occurrence of nonspecific amplification products as reported by Balmas et al. (2) with primers GR70-GR71 could be attributed to the fact that these authors used a very old protocol (17), and not the more stringent conditions adopted more recently $(1,5,12)$ and in this study (i.e., higher annealing temperatures and lower $\mathrm{MgCl}_{2}$ concentration). When using a higher concentration of primers GR70-GR71 than those advised in this study, primer dimers are visible as a consistent DNA band that migrates to about the same extent as the amplicon (data not shown).

To the best of our knowledge, the realtime PCR assay for $P$. tracheiphila described herein is more rapid than those previously described $(1,2,12,17)$. The realtime PCR assay developed here for the Smart Cycler II System (heating ramp rate of $10^{\circ} \mathrm{C} \mathrm{sec}$ ) can complete a run of 40 cycles in 30 min versus the minimum $3 \mathrm{~h}$ required for conventional PCR followed by gel electrophoresis of the amplicons. Generally speaking, $P$. tracheiphila DNA was identified after about only $10 \mathrm{~min}$ (about 13 cycles) of reaction.

Moreover, the real-time PCR assay was more sensitive than the other PCR tests available, in so far as it was possible to detect up to $500 \mathrm{fg}$ of DNA, even if $1 \mathrm{pg}$ of DNA was considered the limit for reproducible DNA quantification. Conventional PCR using the same primer pair detected up to $10 \mathrm{pg}$ of $P$. tracheiphila DNA and, in the rare cases where this method detected 5 pg of DNA, only a very faint band was observed. Under our test conditions, the primer pair designed by Rollo et al. (17) had a detection limit of about $10 \mathrm{pg}$ of $P$. tracheiphila DNA, similar to the limit of the method described by Balmas et al. (2). The high sensitivity of our method, comparable with that of tests using ribosomal genes, probably is due to the high number of target sequences present (16) and the number of copies of cloned DNA target detectable by real-time PCR. Both conventional and real-time PCR assays also were able to detect $P$. tracheiphila in artificially and naturally infected citrus samples, the latter being more sensitive. Real-time PCR and the absolute quantification method (based on either DNA concentration or number of target copies) were able to assess decreasing amounts of the fungus going from the symptomatic tissues toward the asymptomatic ones. Analyzing symptomless sections of lemon twigs from infected plants by real-time PCR determined the presence of about $7 \mathrm{pg}$ of DNA of $P$. tracheiphila.

Hence, the assay seems to be a promising tool capable of quantitatively correlating the presence of the fungus in various lemon cultivars showing different degrees of resistance to $P$. tracheiphila, and of monitoring the efficacy of different control treatments for citrus mal secco like other plant-fungal pathogen interactions $(13,24$, 25,29).

The success and reliability of any PCR assay will depend largely upon the availability of high-yield and representative samples of target DNA also from fieldgrown plants. The simple and rapid extraction method used in this study requires few purification steps in order to maximize yield and quality of recovered DNA, thus allowing rapid processing of many samples. The assay is also faster than the previously proposed ones for the identification of $P$. tracheiphila because the latter are based on PAGE of mycelial proteins and take about 10 days (11). Moreover, up to now, Rollo et al.'s primer pair was used for PCR following an incubation step in agar media or in liquid media, delaying the outcome of the assay by about 3 to 8 days $(1,12,17)$.

The different DNA extraction protocols tested in this study prove that a good bal- ance between cost and time can be achieved. If the identification of a culture of the fungus or diagnosis from symptomatic samples is required, merely lyzing the fungal hyphae in boiling water or performing a rapid DNA extraction with the $\mathrm{NaOH}$ method may enable diagnosis in about $1 \mathrm{~h}$. A portable real-time PCR system, like the one used, together with our simple assay could achieve on-site diagnosis similar to that described for Xylella fastidiosa and Phytophthora ramorum $(22,28)$. Our assay seems reliable for presumptive diagnosis of citrus mal secco disease and analysis of suspected materials in regulated countries.

Results obtained suggest that low fungal concentrations of $P$. tracheiphila, such as those detected in asymptomatic samples, can be achieved only by more efficient total DNA extraction of plant and fungus as opposed to alkaline lysis. Thus, the $\mathrm{NaOH}$ method is not recommended for comparative quantitative studies. Nevertheless, the entire $P$. tracheiphila detection assay could be performed in less than $3 \mathrm{~h}$ using the same DNA extraction kit as the one we used.

The PCR diagnostics described here potentially achieve rapid and accurate identification of $P$. tracheiphila and quantify the presence of the pathogen in citrus tissues. The molecular tool developed currently is being used in our laboratories to quantitatively monitor the fungus in trials on the efficacy of resistance inducers and antagonistic bacteria to the mal secco disease.

\section{ACKNOWLEDGMENTS}

This work was funded by the Italian Ministero delle Politiche Agricole e Forestali project "Ricerca e sperimentazioni nel settore della agrumicoltura italiana". We thank those who provided some of the isolates used in this study, Prof. S. Grasso for guidance, and P. Planchon from Cepheid Europe for helpful advice on real-time PCR.

\section{LITERATURE CITED}

1. Albanese, G., Grimaldi, V., La Rosa, R., Di Silvestro, I., and Catara, A. 1998. PCR analysis applied to citrus mal secco diagnosis. J. Plant Pathol. 80 (3):251.

2. Balmas, V., Scherm, B., Ghigne, S., Salem, A. O. M., Cacciola, S. O., and Migheli, Q. 2005. Characterization of Phoma tracheiphila by RAPD-PCR, microsatellite-primed PCR and ITS rDNA sequencing and development of specific primers for in planta PCR detection. Eur. J. Plant Pathol. 111:235-247.

3. Cacciola, S. O., Perrotta, G., Graniti, A., and Magnano di San Lio, G. 1987. Preliminary examination of strains of Phoma tracheiphila by electrophoresis. Pages 687-691 in: Il Recente Contributo della Ricerca allo Sviluppo dell'Agrumicoltura Italiana. C. Delfino, ed. Sassari, Italy.

4. Catara, A., and Cutuli, G. 1972. Osservazioni sulla suscettibilità di alcune Rutacee alle infezioni epigee di Phoma tracheiphila. Ann. Ist. Sper. Agrumic. 5:29-44.

5. Coco, V., Grimaldi, V., Catara, V., Licciardello, G., Cirvilleri, G., Grasso, S., and Catara, A. Inhibition of Phoma tracheiphila by Pseudomonads in citrus seedlings. Proc. Int. Soc. Citricult. In press.

6. Cutuli, G., and Salerno, M. 1980. On the 
epidemiological meaning of phialospores in Phoma tracheiphila (Petri) Kanc. et Ghik. Pages 72-73 in: Proc. 5th Congr. Mediterr. Phytopathol. Union, Patras, Greece.

7. De Cicco, V., Paradies, M., Ippolito, A., and Salerno, M. 1986. Produzione di fialidi libere di Phoma tracheiphila in condizioni controllate. Phytopathol. Mediterr. 25:107-110.

8. Di Silvestro, I., Cupperi, L., Leonardi, M., and Catara, A. 1988. Investigation on the epidemiology of mal secco through a DNA probe of Phoma tracheiphila. Pages 1949-1954 in: Proc. 6th Int. Soc. Citricult. Tel Aviv, Israel.

9. EPPO/CABI. 1997. Deuterophoma tracheiphila. Pages 733-736 in: Quarantine Pest for Europe, 2nd ed. CAB International, Wallingford, UK.

10. EPPO/OEPP. 2004. Citrus. EPPO/OEPP Bull. 34:43-56.

11. EPPO/OEPP. 2005. Phoma tracheiphila. EPPO/OEPP Bull. 35:307-311.

12. Gentile, A., Deng, Z.N., Tribulato, E., Vardi, A., Albanese, G., Grimaldi, V., and Catara, A. 2000. Evaluation of lemon somaclones for tolerance to mal secco disease by artificial inoculation. Acta Hortic. 535:259-263

13. Mercado-Blanco, J., Collado-Romero, M., Parrilla-Arraujo, S., Rodriguez-Jurado, D., and Jimenez-Diaz, R. M. 2003. Quantitative monitoring of colonization of olive genotypes by Verticillium dahliae pathotypes with real-time PCR. Physiol. Mol. Plant Pathol. 63:91-105.

14. Perrotta, G., and Graniti, A. 1988. Phoma tracheiphila (Petri) Kanchaveli \& Ghikashvili, Pages 396-398 in: European Handbook of the Plant Disease. I. M. Smith, J. Duarez, R. A. Lelliott, D. H. Phillips, and S. A. Archer, eds.
Blackwell Scientific Publications, Oxford

15. Petri, L. 1930. Lo stato attuale delle ricerche sul "mal del secco" dei limoni. Bol. Patol. Veg. Entomol. Agric. 10:63-107.

16. Rollo, F., Amici, A., Foresi, F., and Di Silvestro, I. 1987. Construction and characterization of a cloned probe for the detection of Phoma tracheiphila in plant tissues. Appl. Microbiol. Biotechnol. 451:1-6.

17. Rollo, F., Salvi, R., and Torchia, P. 1990. Highly sensitive and fast detection of Phoma tracheiphila by polymerase chain reaction. Appl. Microbiol. Biotechnol. 32:572-576.

18. Salerno, M. 1964. Ricerche sul "mal secco" degli agrumi (Deuterophoma tracheiphila Petri). L'influenza della temperatura sulla crescita del fungo, sulla produzione e sulla yerminabilità dei picnoconidi. Riv. Patol. Veg. 3:289-299.

19. Sambrook, J., Fritsch, E. F., and Maniatis, T.A. 1989. Molecular Cloning: A Laboratory Manual, 2nd ed. Cold Spring Harbor Laboratory, Cold Spring Harbor, NY.

20. Schaad, N. W., and Frederick, R. D. 2002. Real-time PCR and its application for rapid plant disease diagnostics. Can. J. Plant Pathol. $24: 250-258$

21. Schaad, N.W., Frederick, R.D., Shaw, J., Schneider, W. L., Hickson, R., Petrillo, M. D., and Luster, D. G. 2003. Advances in molecular-based diagnosis in meeting crop biosecurity and phytosanitary issues. Annu. Rev. Phytopathol. 41:305-324.

22. Schaad, N. W., Opgenorth, D., and Gaush, P. 2002. Real-time polymerase chain reaction for one-hour on-site diagnosis of Pierce's disease of grape in early season asymptomatic vines.
Phytopathology 92:721-728.

23. Schaad, N. W., Shaw, J. J., Vidaver, A., Leach, J., and Erlick, B. J. 1999. Crop biosecurity. Feature, September 15 to October 1999. Online publication. American Phytopathological Society.

24. Schena, L., Nigro, F., Ippolito, A., and Gallitelli, D. 2004. Real-time quantitative PCR: new technology to detect and study phytopathogenic and antagonistic fungi. Eur. J. Plant Pathol. 110:893-908.

25. Silvar, C., Díaz, J., and Merino, F. 2005. Realtime polymerase chain reaction quantification of Phytophthora capsici in different pepper genotypes. Phytopathology 95:1423-1429.

26. Solel, Z. 1976. Epidemiology of "mal secco" disease of lemons. Phytopathol. Z. 85:90-92

27. Solel, Z., and Salerno, M. 2000. Mal Secco. Pages 33-35 in: Compendium of Citrus Diseases, 2nd ed. L. W. Timmer, S. M. Garnsey, and J. H. Graham, eds. American Phytopathological Society Press, St. Paul, MN

28. Tomlinson, J. A., Boonham, N., Hughes, K. J. D., Griffin, R. L., and Barker, I. 2005. On-Site DNA Extraction and real-time PCR for detection of Phytophthora ramorum in the field. Appl. Environ. Microbiol. 71:6702-6710.

29. Valsesia, G., Gobbin, D., Patocchi, A., Vecchione, A., Pertot, I., and Gessler, C. 2005. Development of a high-throughput method for quantification of Plasmopara viticola DNA in grapevine leaves by means of quantitative realtime polymerase chain reaction. Phytopathology 95:672-678.

30. Wang, H., Meiqing, Q., and Cutler, A. J. 1993. A simple method of preparing plant samples for PCR. Nucleic Acids Res. 21:4153-4154. 